\title{
THE EXPLORATION OF THE TIETÊ RIVER BY THE COMISSÃO GEOGRÁFICA E GEOLÓGICA (1905): CARTOGRAPHIC ASPECTS
}

\author{
A exploração do rio Tietê pela Comissão Geográfica e Geológica (1905): \\ aspectos cartográficos
}

\author{
Jorge Pimentel Cintra \\ Escola Politécnica da USP - Departamento de Engenharia de Transportes, Av. Prof. Almeida Prado, \\ Travessa 2, no. 83. Cidade Universitária - São Paulo (SP) - Brasil -CEP: 05508-070 \\ E-mail: jpcintra@usp.br
}

\begin{abstract}
:
This paper studies the cartographic products associated with the Tiete River Exploration Report, (1905) published by the Geographical and Geological Committee of the São Paulo Province. The expedition, from the Bar of the Jacaré-Guassú River to the Paraná River, led to the mapping of the Tietê River, which, along with others, is part of the efforts made by this state agency so that there was no longer a great region called "Unknown hinterland inhabited by Indians" in the official map of the Province of Sao Paulo. The purpose was not only to map, but also to raise the mineral resources, the geology, focused on the types of soil and its agricultural potential, and the navigability of rivers for transporting people and goods. The data obtained are studied (altitudes, longitudes, magnetic declination), surveys paths, equipment used, work methodology and the Cartography produced: General Map, Partial Maps, Profile, Cross Sections and others.
\end{abstract}

Keywords: Tiete River Exploration, Comissão Geológica e Geográfica de São Paulo, History of Cartography of Sao Paulo, Cartographic Techniques in the Nineteenth Century

\section{Resumo:}

O presente trabalho estuda os produtos cartográficos associados ao Relatório Exploração do Rio Tietê, de 1905, obra publicada Comissão Geográfica e Geológica da Província de São Paulo. A expedição, da Barra do Rio Jacaré-Guassú ao Rio Paraná, deu origem ao mapeamento do Rio Tietê, que junto com outros, faz parte do esforço realizado por esse órgão para que não mais houvesse no mapa oficial da província de São Paulo uma grande região denominada "Sertão desconhecido habitado pelos índios". A finalidade era não só cartografar, mas levantar as riquezas minerais, a geologia, focada nos tipos de solo e sua aptidão agrícola, e a navegabilidade dos rios para o transporte de pessoas e bens. São estudados os dados obtidos (altitudes, longitudes, declinações magnéticas), os levantamentos de caminhos, equipamentos utilizados, metodologia de trabalho e a Cartografia produzida: Mapa geral, Mapas parciais, Perfil, Seções e outros.

Palavras-chave: Exploração do rio Tietê, Comissão Geológica e Geográfica, História da Cartografia em São Paulo, Técnicas Cartográficas no Século Dezenove 


\section{Introduction}

The Geographical and Geological Committee of the São Paulo Province (CGG) was established in 1886, still in the Empire, by Councilor João Alfredo Correia de Oliveira, President of the Province, who decided not to accept that in the official map there was a large region called "Unknown hinterland inhabited by Indians." He appointed geologist Orville Derby to this Committee. Derby hired Teodoro Sampaio to account for the geographical works.

A priority task was the exploration of the State of São Paulo rivers that ran through this little known region. The goal was not only to map, but knowing the mineral resources, the geology (focused on the types of soil and its agricultural suitability), the navigability of rivers for transporting people and goods (flow of future crops). For each river exploration, a Report was published, a real scientific work, together with the river mapping. These works help to draw a more accurate map of this unknown region, which was also chartered in the Report that shall be examined in this article. See Figure 1.

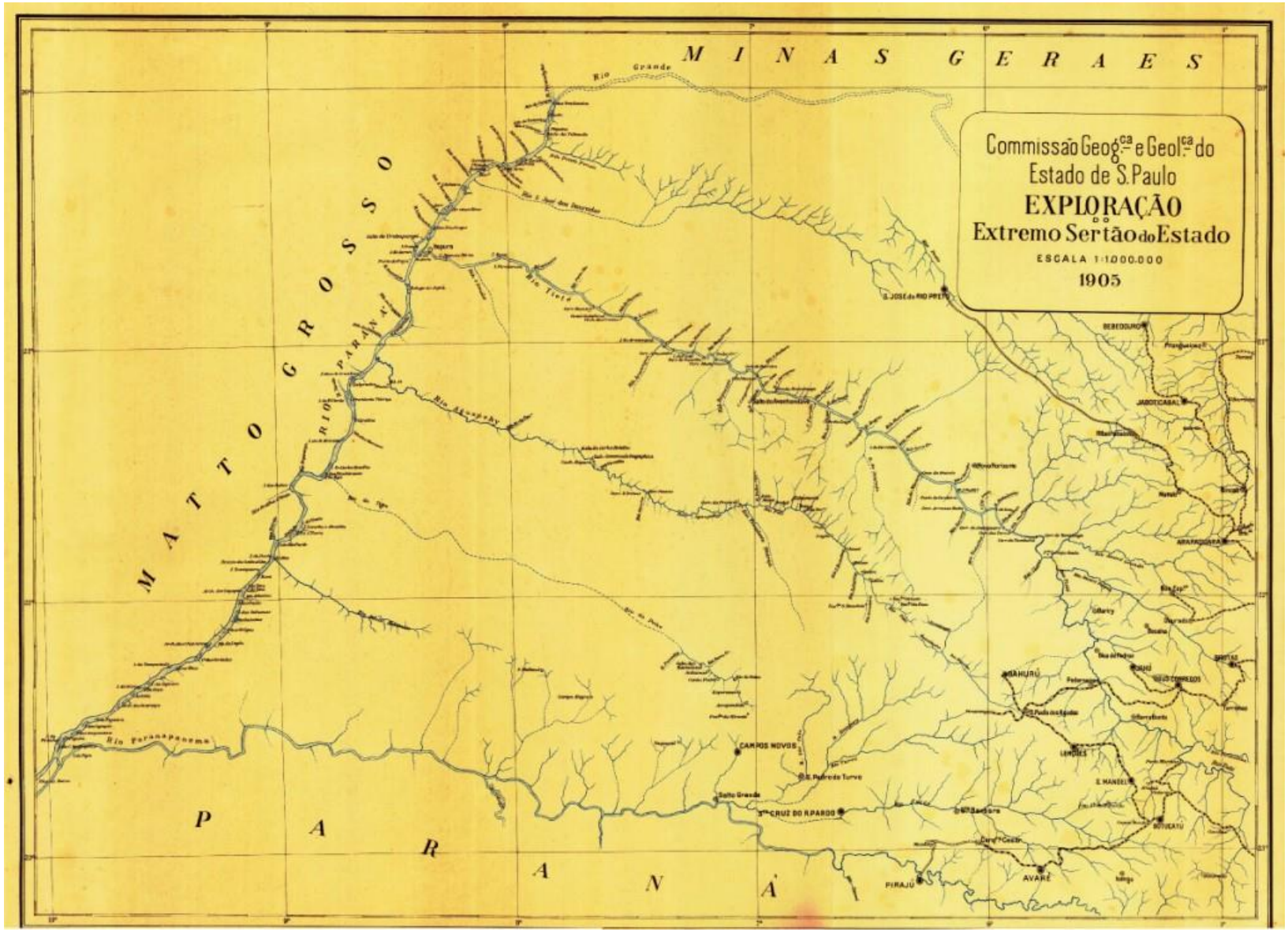

Figure 1: Cartography reformulation based on the survey of large rivers. Source: CGG (1905).

The improvement of mapping is clearly visible when comparing this map with another produced in the mid-nineteenth century. The rivers that have been mapped between 1905 and 1907 are: Paranapanema, Feio or Aguapeí, Peixe, Grande, Paraná and Tietê, on the focus of this work. In parallel to these surveys, the developed region of the State was mapped at 1:100,000, resulting in the mapping that would be used until the 1970s, already discussed elsewhere (Cintra e Silva, 2002). In the other areas covered with difficult penetration forests, the rivers played an important role as the only possible route. 
These rivers exploration reports were analyzed from a historical point of view (Figueroa, 1985, 1987, 2008); iconographic (Moi, 2005), or the works of the CGG as a whole (Lucio, 2014), but there are few studies of its cartographic aspects, more specifically, measurements of altitudes, latitudes, longitudes, magnetic declination, field surveys, equipment and methodology, as well as the maps: the general plan of the river, the eight partial maps, cross sections, profile and others.

Thus, from the cartographic point of view, this study analyses this important work of the CGG, placing it in the historical context and seeking to reveal methodologies and to assess the accuracy and the quality of these products.

\section{The Report about the exploration of the Tietê River and its annexes}

The expedition Report, made in 1905, was published with that date by CGG, although one map is dated 1906, and may have only actually been made available in 1907. It full title is Exploração do Rio Tietê (Barra do Jacaré-Guassu ao Rio Paraná) [Exploration of the Tietê River]. The cover also contains the information: published in the presidential term of Dr. Jorge Tibiriçá, and being Secretary of Agriculture Dr. Carlos J. Botelho. It consists of 18 pages of text and tables. It is presented by the head of the Committee, João Pedro Cardoso, and comprises two parts.

The first part, prepared by engineer Jorge Black Scorrar, group leader, presents an overview of the river, divided into sections dealing with altitude, geographic coordinates, vegetation and soil, flora, paths, geology, Indians, former military colonies and notes on the weather. Five tables contain the report summarizing and quantifying data: rapids, islands, geographic coordinates, tributaries from one bank and the other.

The second part, drawn up by Guilherme Florence, is entitled Notas geológicas sobre o rio Tietê (geological notes on the Tiete River) and its last two pages are devoted to the relationship of camps and dates, along with the data of the daily measurements of air and water temperature.

Without page numbering, this report includes many photographs and maps, among which we highlight:

a) The so called Planta Geral do Rio Tietê, scale 1:500,000, with a network (lines) of geographical coordinates. This network is turned so that the river is approximately parallel to the edges of the drawing. Also included are the paths connecting the villages of Novo Horizonte and São José do Rio Preto to the river. In this overview the surrounding rectangles of the eight partial maps are drawn.

b) The eight Mapas parciais (partial maps), scale 1: 50.000, on numbered sheets from I to VIII, which also have a network of geographical coordinates. They also include: cross sections, tributaries, rapids, islands, and dimensions in some points (width, depth), and the numbered camp sites.

Moreover, there are indications of equipment used in the measurements, and the indication of a few topographic survey processes. Others process will be deducted in this work.

Under the leadership of engineer Jorge Black Scorrar, there was a team of others engineers who would stand out over time, as well as a geologist, Guilherme Florence, and a doctor, Mamede da Rocha. They left Bariri on foot, from where they proceeded to the port Laranja Azeda. 
The expedition was widely documented by photographs. The descent of the river was greatly difficulty, owing to the rapids and the waterfalls, as occurred at the time of the monsoon. The crossing of one of the waterfalls, the Cachoeira das Cruzes can be seen in Figure 2. In the waterfalls, such as Avanhandava and Itapura, the transposition was made by land and this required some days.

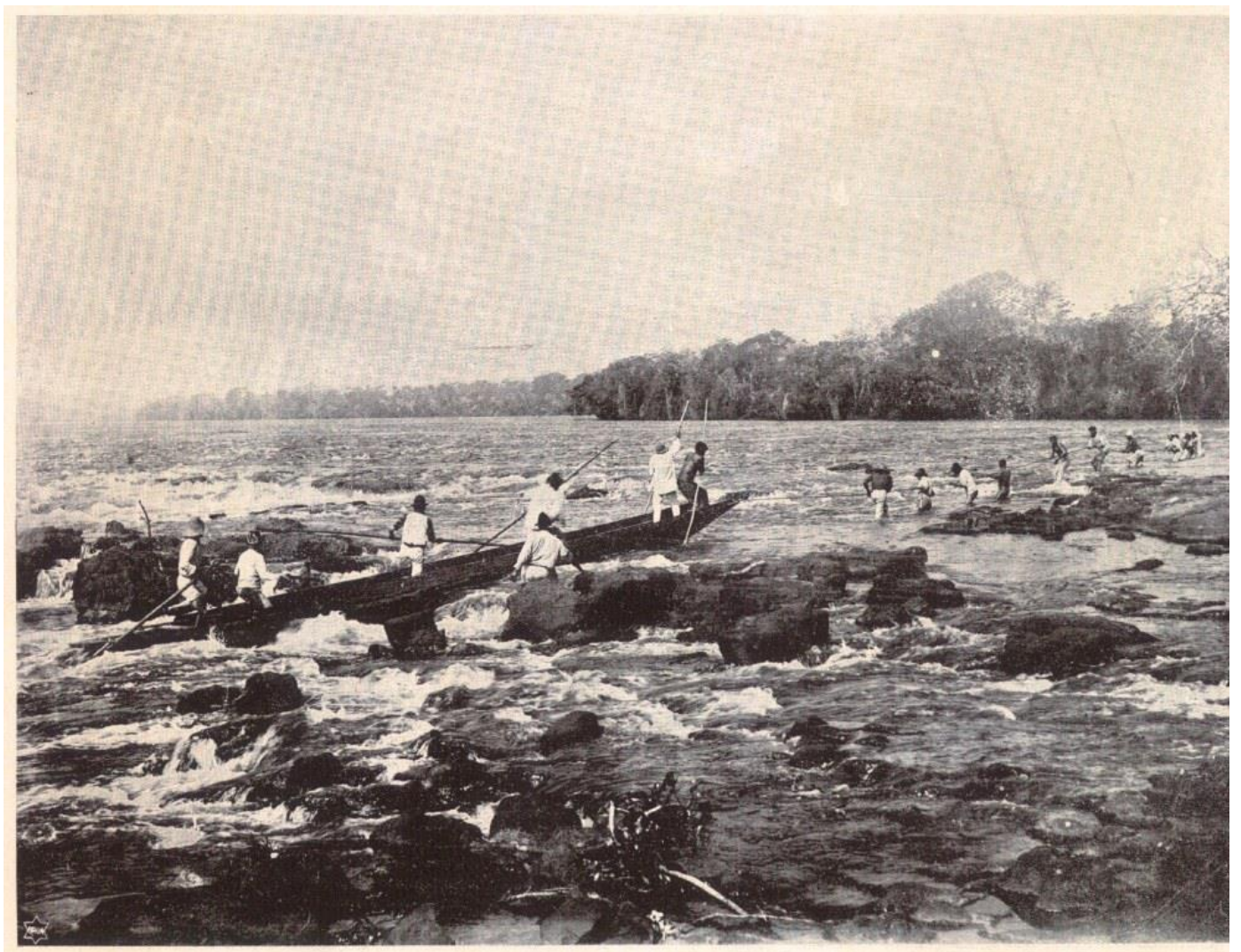

Figure 2: Cachoeira das Cruzes, in the ascent operation. Source: CGG (1905).

The report gives a general description of the river, dividing it into sections and highlighting some landforms, such as the so-called Rio Morto, a designation that comes from its little current, no rapids and straightforward navigation. The format is $330 \times 455 \mathrm{~mm}$, and the maps and photos are foldaways and have even larger formats up to $330 \mathrm{x} 976 \mathrm{~mm}$.

In the next sections, we present the data collected in the field, the methodology employed, taking into account the report, equipment available, technology and methods at that time, and the cartographic production itself.

\section{Cartographic data}

a) Altitudes. The altitudes were measured by barometric pressure using the differential method applied between Matão, where there was a permanent weather station, and the place of departure (Porto de Laranja Azeda) and of arrival (Tietê Bar in the Paraná River). They also conducted a run survey, whose methodology is specified as follows.

b) Latitudes, Longitudes and magnetic declination. Table 1 summarizes the survey of geographical coordinates made by the team, indicating latitude, longitude, and magnetic declination. The longitudes are represented both in arcseconds and in time. As will be discussed, there are some inconsistencies between the values provided for the first point since $23 \mathrm{~min}$ and $0.53 \mathrm{~s}$ correspond 
to $5^{\circ} 45^{\prime} 08^{\prime \prime}$, and not to $5^{\circ} 44^{\prime} 48^{\prime \prime}$, as shown in the table. The declination is the angle between the true north and the magnetic one, which varies from place to place (as shown) and that is an important element for mapping the river.

Table 1: Geographical coordinates and magnetic declination

\begin{tabular}{c|c|c|c|c}
\hline Location & Latitude & Longitude in arc (W) & Longitude in time (W) & Declination \\
\hline Laranja Azeda & $21^{\circ} 51^{\prime} 44^{\prime \prime}$ & $5^{\circ} 44^{\prime} 48^{\prime \prime}$ & $23 \mathrm{~min} .0 .53 \mathrm{~s}$ & $4^{\circ} 5^{\prime} \mathrm{NW}$ \\
\hline Porto do Cordeiro & $21^{\circ} 35^{\prime} 49^{\prime \prime}$ & - & - & $3^{\circ} 5^{\prime} \mathrm{NW}$ \\
\hline Avanhandava & $21^{\circ} 13^{\prime} 41^{\prime \prime}$ & $6^{\circ} 45^{\prime} 29^{\prime \prime}$ & 27 min. $0.93 \mathrm{~s}$ & $3^{\circ} 0^{\prime} \mathrm{NW}$ \\
\hline Porto 14 de julho & $21^{\circ} 13^{\prime} 15^{\prime \prime}$ & $6^{\circ} 49^{\prime} 48^{\prime \prime}$ & $27 \mathrm{~min} .19 .20 \mathrm{~s}$ & $3^{\circ} 0^{\prime} \mathrm{NW}$ \\
\hline Itapura (Church) & $20^{\circ} 39^{\prime} 04^{\prime \prime}$ & $8^{\circ} 19^{\prime} 28^{\prime \prime}$ & $33 \mathrm{~min} .17 .87 \mathrm{~s}$ & $2^{\circ} 1^{\prime} \mathrm{NW}$ \\
\hline Barra do Tiete & $20^{\circ} 40^{\prime} 13^{\prime \prime}$ & $8^{\circ} 24^{\prime} 16^{\prime \prime}$ & $33 \mathrm{~min} .37 .07 \mathrm{~s}$ & $1^{\circ} 25^{\prime} \mathrm{NW}$ \\
\hline
\end{tabular}

c) Surveys. Different paths surveys were made notably from the river to the two cities (Novo Horizonte and São José do Rio Preto), village plans, such as Avanhandava and of the military colony of Itapura.

\section{Equipment and methodology employed}

a) Equipment. The report allowed knowing the instruments used and Table 2 is a list of them, indicating the variables that they can measure directly or indirectly. In an incident in rapids, the waters invaded the luggage barge and three aneroids, the barometer recorder (Fortin) and two thermometers were destroyed. This leads to the conclusion that they had more than one device of each type.

Table 2: Equipment and physical quantities they can measure

\begin{tabular}{l|l}
\hline Type of equipment & Measurable quantities \\
\hline Lugeol Spyglass & Distances, by telemetry \\
\hline Gurley Level & Differences in level \\
\hline Woltmann Windlass & Speed of the current, Flow rate \\
\hline Casella Aneroids & Pressure, Altitude \\
\hline Patek Philippe Chronometer & Time, Longitude \\
\hline Keuffel \& Esser Theodolite & Angles, Distances, Difference of level \\
\hline Sextant & Angles and Latitude \\
\hline Fortin Barometer & Pressure and Altitude \\
\hline Pedometer & Number of steps, Distance \\
\hline Prismatic compass & Magnetic azimuth, Angles \\
\hline $\begin{array}{l}\text { Thermometers: simple, maximum and minimum and } \\
\text { recorder }\end{array}$ & Temperatures \\
\hline
\end{tabular}


b) Division of tasks. From the description, it is known that engineer Guilherme Wendel was responsible for geographical coordinate determinations, weather and other such complex tasks, which required theoretical knowledge and operational practice. Guilherme Florence was in charge of the geological studies and the auxiliary staff were distributed as follows: Arthur O'Leary and Fructuoso Costa surveyed the left bank; Alexandre Cococi and Dagoberto Silva surveyed the other bank,.

The latter distribution implies that each team would be concerned with the landforms (e.g. tributaries) of one of the banks, which is practical as it would not be necessary to cross the river. The data contained in the report and mapping indicate that they collected place names (toponymy) and width of each tributary bar, as well as their extent of exploitation upstream; in addition to the draft of the margins, indicating the camp sites, etc. This does not exclude some work done inland such as the contour lines that appear from time to time, survey of some ways and others. Yet often this was hindered due to the dense vegetation. The two teams might have worked together in special tasks, as when surveying falls and cross sections.

c) Survey of rivers and paths. The mileage was zeroed in Jacaré Grande Bar as explicitly stated in the map I. From there onwards, the distances covered by means of the Lugeol lunette (tachometer) were measured, along with the speed of the canoes with respect to banks and the time of navigation; the compass and some calculations allow determining the azimuth and calculating the projection of the distances in the north and east axis.

In land, the way was surveyed with compass and pedometer, linking the farms Laranja Azeda, Vamicanga and Porto Ribeiro to their ports; and also the survey of some roads, such as Garbarino Port to Novo Horizonte $(16.5 \mathrm{~km})$. For others, as stated in the report, they used the theodolite and stadia: from Avanhandava to Fartura $(49 \mathrm{~km})$, continuing to São José do Rio Preto $(93 \mathrm{~km})$ and also the road linking Colonia Itapura to Saltinho, in a branch of the Paraná River $(6 \mathrm{~km})$. In some cases, they used theodolite and stadia, which increased the efficiency and accuracy of the work.

d) Determination of the true north. As pointed out, for drawing the river, it is necessary to have directions with respect to the true north, i.e., true azimuth and not only magnetic azimuths. Thus, it is necessary to know the magnetic declination, which is the angle between them, which varies from place to place. Table 1 presents this information, which means they were determined.

For this, the process employed at the time employed the compass to determine the magnetic azimuth of a well-defined and long line (to minimize pointing errors) and then by an astronomical process, to determine the true azimuth. By an observation made in the report, the declination was verified to be determined by "heights of astros (stars) out of the meridian line." In fact this expression refers more specifically to determining the north, which is one of the data for calculating declination. Astros seems to more adequately refer to the stars, since if it were the sun, it would have been made explicit. Then, the process is that of observing a star at the same height, upwards (before culmination) and the symmetrical position, downwards. The bisector of the horizontal angles provides the direction of the meridian, or north-south line. Their theodolite was the instrument for this.

Having the declination at each point, all the mapping can be referred to the true north and the meridians and parallels can be drawn, once the type of projection has been chosen.

e) Drawing of cross sections and calculation of flow rates. To perform the layout of these sections, it is necessary to travel the river perpendicularly to the current (or the banks) and to select a point of origin in one of the banks, launching sounding instruments at known distances. Launching probes (with a rope with a weight at the end) does not seem rather complicated, due to the shallow depth (between 1 and $2 \mathrm{~m}$ ). The alignment can be maintained with the theodolite; the most demanding operation is measuring the distance perpendicular to the current; extend strings or wires 
requires equipment with long lengths, since the width of the river easily reaches 200 to $300 \mathrm{~m}$, as shown by the data.

The speed measurement $(\mathrm{m} / \mathrm{s})$ of the current in an average depth (in points along the section) allows calculating the flow or discharge as the product of this magnitude by the cross-sectional area $\left(\mathrm{m}^{2}\right)$, resulting in the data for five locations: 12 measurements made between the Jacaré Grande and Avanhandava, resulting in a flow of $363 \mathrm{~m}^{3} / \mathrm{s}$. The average in the stretch from Avanhandava to Pontal was $352 \mathrm{~m}^{3} / \mathrm{s}$. In the waterfalls of Macuco and Cruzes, 368 and $357 \mathrm{~m}^{3} / \mathrm{s}$, respectively, and in the rapids of Ilha Seca, $378 \mathrm{~m}^{3} / \mathrm{s}$.

In one passage for the Avanhandava waterfall, the report provides the following information: height difference of $17.57 \mathrm{~m}$, flow of $263 \mathrm{~m}^{3} / \mathrm{s}$, and then the power that could be generated is 61,600 horsepower (HPs); and for Itapura, 54,700 HPs. These calculations, which we checked to be correct, show concern for the use of this hydropower potential.

f) Altitude measurement. The way these measurements were made is indicated implicitly in the report: two Fortin barometers were employed; with one located permanently in the weather station of Matão and the other in Laranja Azeda, and later in the Pontal. That is, simultaneous observations, configuring the differential technique which produces good results, whenever atmospheric conditions can be considered homogeneous at both ends of the base, which is not always valid, taking into account the distance of about $400 \mathrm{~km}$ between Matão and Pontal.

For verification purposes, they made an ingenious survey that can be seen in the Report: they measured the height differences in waterfalls and cascades both using the theodolite and the Gurley level and determined the average slope in calm water sections $(0.13 \mathrm{~m} / \mathrm{km})$ multiplying this value by the whole extension in this condition. There was a good coincidence between the two processes. This provided security for the intermediate values of heights obtained for draw the profile.

Numerically, Matão is at an elevation of $560 \mathrm{~m}$ above the mean sea level; by difference they calculated the quota in the Port Laranja Azeda $(393 \mathrm{~m})$ and Tietê bar $(271.5 \mathrm{~m})$, resulting in a difference of $122.5 \mathrm{~m}$. By run leveling, as they called the process described above, the elevation transported to the bar was $271 \mathrm{~m}$ (and height difference of $122.0 \mathrm{~m}$ ), showing that the difference between the two methods was only $0.5 \mathrm{~m}$.

g) Temperature measurement. This is the easiest operation. There were three daily measurements, of the air and of the water, at $7 \mathrm{am}, 1 \mathrm{pm}$ and $7 \mathrm{pm}$, also recording the maximum and minimum temperature. For this, they had two maximum and minimum thermometers and two simple ones. The table shows that the measurements were very constant and that the averages were calculated in each location (landing/camp) when they stayed longer than one day. Table 3 shows the extreme temperatures recorded.

Table 3: Maximum and minimum temperatures for each month

\begin{tabular}{c|c|c}
\hline Month & maximum & minimum \\
\hline June & $30^{\circ}$ & $2^{\circ}$ \\
\hline July & $30.5^{\circ}$ & $6.5^{\circ}$ \\
\hline August & $32.5^{\circ}$ & $1.5^{\circ}$ \\
\hline September & $32.2^{\circ}$ & $12^{\circ}$ \\
\hline
\end{tabular}

The temperature measurement is also of direct interest to the agricultural potential, one of the expedition objectives, also verified in the geological and soil studies, especially the red earth (terra roxa), already widely used at that time for growing coffee. 
h) Geographical coordinates determination. The geographic determinations (latitude and longitude) were made at the sites indicated in Table 1 ( 5 longitudes and 6 latitudes). The operations require some time and quiet; in some places, this appears clearly: they stayed seven days in Laranja Azeda, eight in Avanhandava, , and six in Itapura.

In the item Geographical coordinates of the Report, the instruments available for the expedition are specified and the accuracy or minimum division for direct reading is indicated: Theodolite Keuffel \& Esser (mistakenly spells Heuffel) with 10" division for the horizontal circle and 20" to the vertical; a sextant, with minimal division of $5 "$ and a Patek Philippe chronometer, $0.2 \mathrm{~s}$ of accuracy. It also indicates that the night lighting was by acetylene lamps, which indicates that some or many celestial observations were at night: the stars and the moon.

There is a short paragraph which allows deducing the methods employed. For example: "The process for determining was culmination". It is understood that it is the latitude $\varphi$ of the place, because, at the culmination, the stars cross the meridian of the place. In addition to determining the north-south line, it allows calculating the latitude by measuring the height $\mathrm{h}$ of the star, and consulting an ephemeris almanac, get the declination $\delta$, and then performing the calculation: $\varphi=$ $\mathrm{h}+\delta-90^{\circ}$.

To determine longitudes theoretically with the equipment they had, they could simply follow the pace of the chronometers and check the time difference to Paris, London or Rio de Janeiro. They could also use the process of lunar distances, which is to measure the height of the moon and a star, and the distance (angle) between them, something possible with the sextant they had.

The heights of the two stars are used to correct the angular distance and to get the time and, therefore, the length. However, none of these methods worked, explains the Report, " numerous observations of lunar distances and time were also made, but they were not taken into consideration for giving unsatisfactory results and also for the chronometer pace being very irregular."

Next, it states: "The longitude of Avanhandava was determined by lunar culminations and the one of Itapura with lunar heights." Culmination consists in observing the Moon in the meridian passage, and height means the measurement of this value (height) for the Moon. This information is not sufficient to deduce the method used; perhaps they employ a particular case of lunar distances, when the Moon crosses the meridian and then measure its height.

Problems with chronometers happened to Teodoro Sampaio who did not manage to use any of the three he had with him in 1886, in the survey of the Paranapanema river. The same occurred with the astronomers who made the surveys for delimiting the border between Brazil and Argentina, in 1895.

Next, the Report states that there was another team up the Paraná River and between the two sets of measurements, there was a gap of a few seconds, which led him to take the average between the two sets to fit the Tietê works, surveyed with a Lugeol tacheometer (i.e., the distances was surveyed with this equipment). Euclides da Cunha, Luis Crulz and Rondon also used this equipment in their work, and sometimes complained about the long time required by this process.

Finally, with the data, the engineers concluded that the previous maps of the region contained errors in some coordinates: Avanhandava waterfall was moved $24 \mathrm{~km}$ north and $4.5 \mathrm{~km}$ to the west; the Itapura waterfall, $41 \mathrm{~km}$ to the north and $7 \mathrm{~km}$ to the west, and the Tietê Bar, $46.5 \mathrm{~km}$ to the north and $6 \mathrm{~km}$ to the west. A non-negligible error and was thus corrected and better maps could be counted on. 


\section{Cartography of the Tietê River}

\subsection{The cover map}

On the cover, the Report presents a situation map: South America, Brazil (sic) and the State of São Paulo. The scale chosen was 1: 60,000,000, to make it suitable to the space available. The Pacific and the Atlantic Ocean names appear drawn along the coast. Only the main rivers are shown and only the capitals of the States at the time, with the exception of Santos, which is also depicted.

Brazil's borders, by the effect of the scale, are not drawn accurately, simplifications being also verified in Rio Grande do Sul and in the Territory of Acre, then recently incorporated to the country. The countries boundaries are also greatly simplified, the Guianas not being divided in three, and Ecuador appears presented as having limits with Brazil, which was under discussion at the time.

The longitude is growing to the left and the meridian of origin is not a single one: there are two graduations; the top one results in about $46^{\circ}$ to Rio de Janeiro, which points to Paris as the meridian of origin; to reach this value, $43.2^{\circ}$ must be added (of Rio de Janeiro with respect to Greenwich) with $2.5^{\circ}$ (Greenwich to Paris); the other graduation results in $30^{\circ}$, which rules out the possibility of the Ilha do Ferro meridian (common at the time) and seems to refer to the Cape Verde Islands, more specifically, Santo Antão.

A more accurate map would be necessary for the calculations. Anyway, the meridian point of origin is a marginal issue in this map, which only aims to situate the study area.

Regarding the projection, the distance between the divisions (from 10 to 10 degrees) is verified to be constant, and equal in latitude and longitude, which indicates it is a Plate Carrée projection (Equirectangular Projection).

\subsection{The general plan of the Tietê River}

a) The construction of the drawing. This plant, as can be seen in Figure 3, from the bar of the Jacaré Grande river to Pontal, is in the scale of 1: 500,000, which is suitable for this type of assembly representation. Once the scale has been chosen, the next step is drawing the network of coordinates (latitude and longitude), wherein the reference points for the design (Table 1) are in this type of coordinates. A draft allows determining the larger dimension of the design and calculating the general direction of the river: from the Bar of the Jacaré Grande to Avanhandava, the orientation is $51^{\circ}$ northwest, after $14^{\circ}$ leaning toward Itapura and then heading west toward the headland. This allowed applying a turning of the grid so that the general direction of the river is approximately parallel to the edge of the sheet. A measurement of the general plan indicated a $26.5^{\circ}$ counter-clockwise turning of the mesh. 


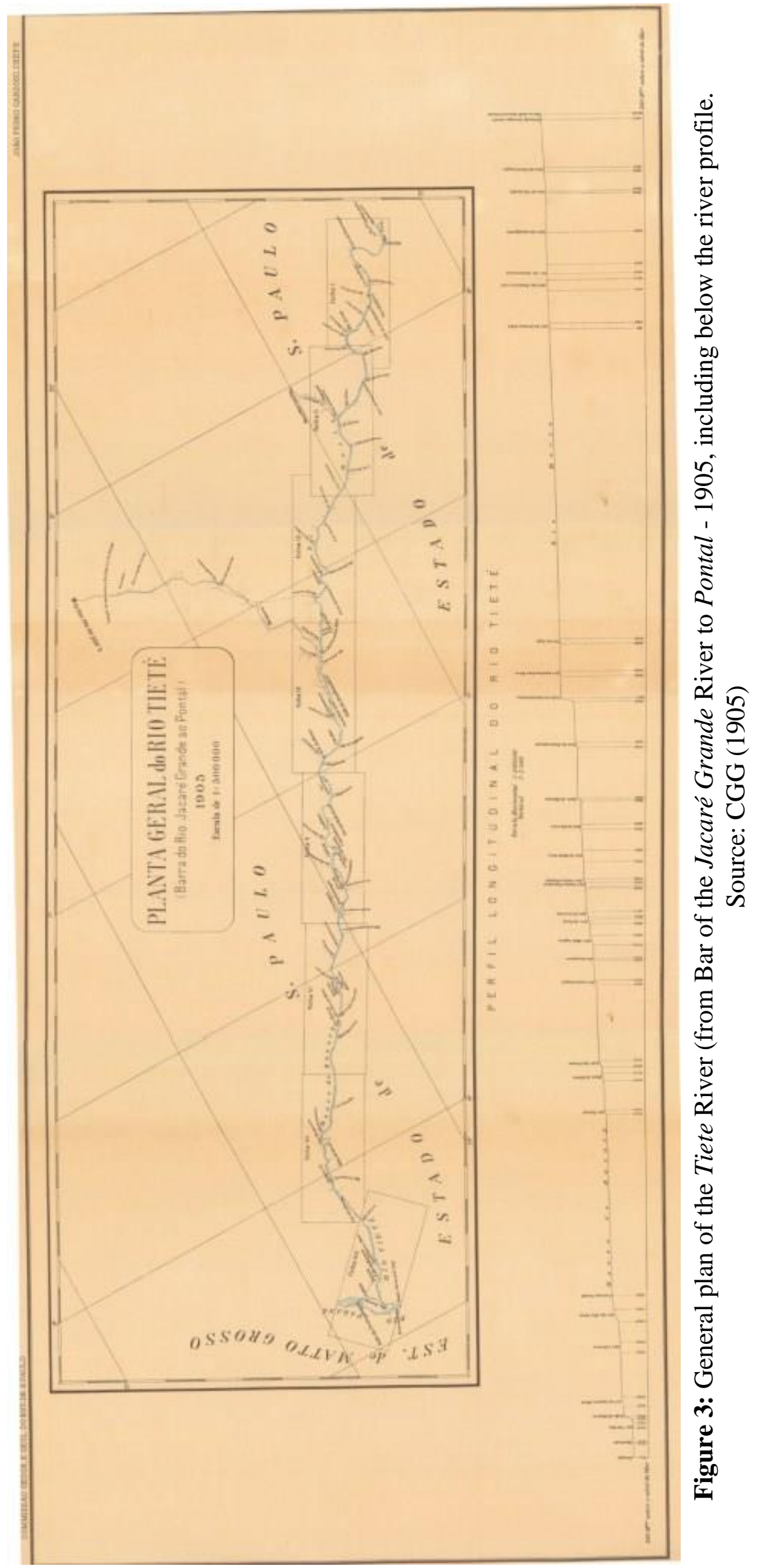

Bol. Ciênc. Geod., sec. Artigos, Curitiba, v. 23, no2, p.309 - 326, abr - jun, 2017. 
To determine the coordinates of the various geographical features and to draw them, the process begins at a point with coordinates determined astronomically, in this case, the port of Laranja Azeda. Next, the distance is assessed with the Lugeol tacheometer or the shipping time at some speed, and the magnetic azimuth with the compass, which are corrected with the magnetic declination. Next, employing the sine and cosine of the true azimuth (A), the component in the direction North and East is projected. These components, divided by the radius of the curvature of the earth provide the difference in coordinates, latitude $(\Delta \varphi)$ and longitude $(\Delta \lambda)$, which are added to the previous point.

Note that the meridian radius of curvature is the radius of the earth itself $(\mathrm{R})$; the parallel radius is that of the earth multiplied by the cosine of the mean latitude (in this case, $21^{\circ}$ ). These coordinates are transported recursively until the next reference point where the geographic coordinates are known (Table 1). At this point, one can check the error and make the distribution in proportion to the magnitude of the projections. And thus on, until the Tietê Bar. The end result are the coordinates of all the points and the drawing can be made, taking into account the projection system.

A problem in this scheme, as with La Condamine, is that if the coordinates of one point of reference contain an error, it will be distributed or spread over all the intermediate points (Cintra and Freitas, 2011).

To analyze the distribution of these control points, we analyzed the distance between them, by the distance in kilometers in the general plan (Table 4). The pairs of points 1,2 and 4, 5 are verified to be very close. But this is what was possible to measure and, as will be seen, this distribution did not significantly damage the cartography adjustment.

Table 4: Distribution of control points

\begin{tabular}{c|c|c|c|c}
\hline $\mathbf{N}$ & Place & Distance in Km (km) & Distance to the next point (km) & Sheet \\
\hline 1 & Laranja Azeda & 0 & 158 & I \\
\hline 2 & Avanhandava & 158 & 8 & IV \\
\hline 3 & Porto 14 de julho & 166 & 193 & IV \\
\hline 4 & Itapura (Church) & 359 & 11 & VIII \\
\hline 5 & Bar of Tiete & 370 & - & VIII \\
\hline
\end{tabular}

b) Determination of the zero meridian. For this task, Table 5 was constructed as follows. For each location, the longitude data of CGG $(\lambda c)$ are provided in the Report (Table 1, with respect to the meridian of origin), but transformed to degree and fraction to facilitate the accounts and with negative sign (west). Also, there was an incongruous value in location 1: longitude $5^{\circ} 44$ ' 48 "(or 5.74667 in degree and fraction or $22 \min 59.2 \mathrm{~s}$ ) does not match $23 \mathrm{~min}$ 0.53s (5.75221 in degree and fraction or $\left.5^{\circ} 45^{\prime} 08^{\prime \prime}\right)$.

Which of the two data is correct? For further calculations purposes, we adopt the second possibility as correct, which produces less error in the Deviation column. The next column reports the longitude $(\lambda i)$ taken of a current IBGE map and therefore referred to the meridian of Greenwich. With these two columns, we can calculate the longitude of origin ( $\lambda$ or) relative to Greenwich as in (1), whose elements were explained above.

$$
\lambda_{\text {or }}=\lambda_{\mathrm{i}}-\lambda_{\mathrm{c}}
$$


Table 5: Calculations for determining the zero meridian

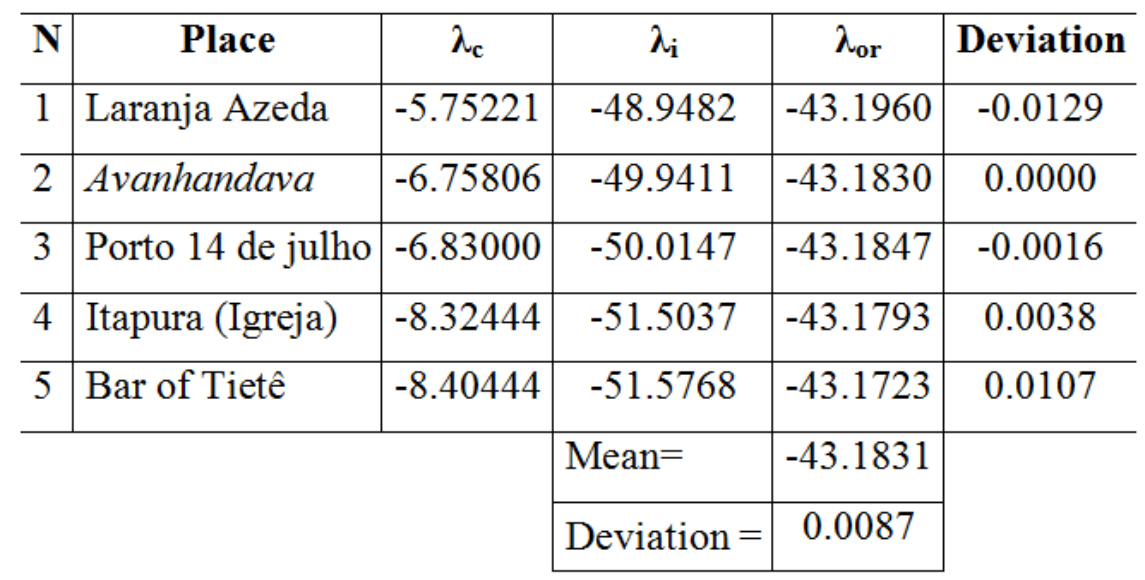

As a result, the calculation of the longitude of the meridian of origin of this map is obtained with respect to Greenwich. The mean and standard deviation show that the five values are quite consistent and measurements were made accurately. The value found $\left(43.1831^{\circ}\right)$ indicates that the meridian of origin is the Morro do Castelo, Rio de Janeiro. This was the origin of many Brazilian maps since the determinations of the Mathematical Priests (Diogo Soares and Domingos Capassi) in the first decades of the eighteenth century. In a way, this was expected because the 1: 100,000 mapping of CGG explicitly states this fact. The greatest errors regarding the average (outlets) are shown at both ends. We analyze how these errors are reflected in the maps further on.

c) The determination of the map projection. To determine the map projection system, the coordinates grid should be analyzed by checking the shape of meridians and parallels (rectilinear or curvilinear), the spacing between them and other variables, as can be seen in Gaspar (2005). In Annex $\mathrm{C}$ of this work, there is a decision tree for it. The analysis of these lines shows that they are straight, with enough approximation, and intersect at right angles; thus, the projection is determined by the spacing between the parallels and, more specifically, the ratio between consecutive parallel spacing and between parallels and meridians. In a copy of the map we obtained $68 \mathrm{~mm}$ between parallel and $58.5 \mathrm{~mm}$ between meridians taken with $0.5^{\circ}$ spacing. The ratio is therefore equal to $\mathrm{k}=68 / 58.5=1.162$.

It can hence be said that is not an equirectangular projection, in which case the ratio would be $\mathrm{k}=$ 1. It is not the projection called Increasing latitudes, either, in which case the ratio would be $\mathrm{k}=1$ $/ \cos (\varphi)=1.075$ (for the average latitude of $21.5^{\circ}$, which well represents the region). Next, we tested the hypothesis of conic or polyconic projection. Being a small stretch of the map, the meridians that would converge on the pole are shown parallel considering the accuracy of the measurements; the parallels that are curved with the concavity turned to the south pole are similar to straight lines, as in the map of Brazil to the millionth, where this curvature is not noticeable. For this projection, the proportion factor is $1 / \cos ^{2}(\varphi)=1.155$ which is very close to the value found (1.162), resulting in a difference of -0.007 , which could be explained by a $0.5 \mathrm{~mm}$ error in the measurement of the distance between the lines of the grid, dilation of the paper, etc.

This hypothesis (conical or polyconic projection, which in practice are identical in a small portion of variation in latitude) is thus a good assumption, being favored by the fact that this projection was used in the 1: 100,000 of CGG map project which was being developed in parallel with the exploitation of rivers (Taliberti, 1962, p. 25); we therefore adopted it.

d) Assessment of the geometrical quality of the map. This map was scanned from the Report, with a resolution of 300 dpi. This is an original color map, with the river in blue, old paper (yellow), latitude and longitude markings of $30^{\prime}$ by $30^{\prime}$ and the sheet sequence indication from I to VIII. 
Once the coordinates mesh was recorded, it was possible to extract the coordinates of several notable points of this map for later comparison.

As reference cartography, the maps from IBGE, scale 1:250,000, were taken recovering the charts through which the river Tietê flows, namely: Andradina, Araçatuba and Votuporanga. These maps are available on the IBGE site, only the layer of hydrographic network being used, which provides the four corner marks, enough to register the map.

Table 6 compares the coordinates measures in the field, with those of the map. For this the coordinates are observed not to be carefully transferred from the table to the map, that is, there has been some maladjustments. To assess this error, the average difference in longitude can be calculated: value 0.009 corresponds in this latitude to about $900 \mathrm{~m}$, which, on the scale of the map (1: 500,000) is equivalent to $1.8 \mathrm{~mm}$. Another case: in the Tietê Bar, the 0.0218 value equals 4.2 $\mathrm{mm}$, clearly noticed by the measurements we made on the map.

Table 6: Comparison between the coordinates of the field with that of the map

\begin{tabular}{|c|c|c|c|c|c|c|}
\hline Place & \multicolumn{2}{|c|}{ Report } & \multicolumn{2}{|c|}{ Map } & $\Delta \varphi$ & $\Delta \lambda$ \\
\hline Laranja Azeda & -21.86222 & -5.75221 & -21.8710 & -48.9286 & 0.00873 & -0.00670 \\
\hline Avanhandava & -21.22806 & -6.75806 & -21.2359 & -49.9504 & 0.00783 & 0.00929 \\
\hline Porto 14 de julho & -21.22083 & -6.83000 & -21.2201 & -50.0189 & -0.00078 & 0.00581 \\
\hline Itapura (Church) & -20.65111 & -8.32444 & -20.6554 & -51.5225 & 0.00431 & 0.01496 \\
\hline Bar of the Tietê & -20.67028 & -8.40444 & -20.6610 & -51.6093 & -0.00930 & 0.02181 \\
\hline & & & & Mean $=$ & 0.00216 & 0.00903 \\
\hline & & & & Deviation $=$ & 0.00084 & 0.01218 \\
\hline
\end{tabular}

The next step was to check this map as a whole, that is, to analyze the coordinates of the intermediate points, which, in addition to the above errors, contains those made in the coordinate transport operation and adjusting them.

Also with the digital mapping program (MapInfo), the coordinates of 36 points were extracted, taking care that they were relatively evenly spaced and well distributed by the 8 partial topographic maps ( 4 or 5 points in each). Thus, Table 7 was designed, in which, as in Table 5, index c corresponds to the coordinates in the partial maps of CGG, index $\mathrm{i}$ to the IBGE map. The $\lambda \mathrm{g}$ column corresponds to the longitude of the point in relation to Greenwich, which is obtained by adding the constant -43.1831 determined above (longitude of the Morro do Castelo with respect to the British observatory).

The spelling was maintained as is presented in the Report and C. means Córrego (Stream); Corr. Corredeira (rapids); Rib. Ribeirão (Stream), Cach. Cachoeira (Waterfall) and I. Ilha (Island).

As can be seen by comparing the last two tables, the mean (measuring the systematic error), does not vary much if we consider 5 control points or all the 36 . The standard deviation, which measures the accuracy, worsened, more sharply in latitudes. A fact that could explain this is the representation of the river, with double border and a thickness of $2 \mathrm{~mm}$. We decided to set the points at the center of the double border line, but the coordinates could match one of the banks, perhaps one into which the tributary flows, for example. 
Table 7: Determination of the accuracy of the map coordinates at points along the river

\begin{tabular}{|c|c|c|c|c|c|c|c|c|}
\hline n & Place & $\varphi_{\mathrm{s}}$ & $\lambda_{s}$ & $\lambda_{3}$ & $\phi_{i}$ & $\lambda_{i}$ & $\Delta \varphi$ & $\Delta \lambda$ \\
\hline$\overline{1}$ & Larayja Areda & -21.8710 & -5.7455 & -48.9286 & -21.8414 & -48.9482 & -0.0296 & 0.0196 \\
\hline 2 & C. da Monçdo & -21.7877 & -5.8531 & -49.0362 & -21.7552 & -49.0172 & -0.0325 & -0.0190 \\
\hline 3 & Corr. dos Porcos & -21.7729 & -5.8914 & -49.0744 & -21.7423 & -49.0416 & -0.0306 & -0.0328 \\
\hline 4 & Rib. Batalha & -21.6932 & -6.0156 & -49.1986 & -21.7061 & -49.1707 & 0.0129 & -0.0279 \\
\hline 5 & Rio da Sucwy & -21.6709 & -6.0810 & -49.2641 & -21.6939 & -49.2202 & 0.0230 & -0.0439 \\
\hline 6 & Rib. 3 Pontes & $\mid-21.5940$ & -6.1326 & -49.3157 & -21.6115 & -49.2712 & 0.0175 & -0.0445 \\
\hline 7 & Rio do Barreiro & -21.5638 & -6.1461 & -49.3292 & -21.5721 & -49.3409 & 0.0083 & 0.0117 \\
\hline 8 & C. do Cendo & -21.5612 & -6.1572 & -49.3403 & $\mid-21.5911$ & -49.2923 & 0.0299 & -0.0480 \\
\hline 9 & C. do Macuco & -21.5221 & -6.2915 & -49.4746 & -21.5379 & -49.4463 & 0.0158 & -0.0283 \\
\hline 10 & Rib. Barra Mansa & -21.3704 & -6.4285 & -49.6116 & -21.3689 & -49.6219 & -0.0015 & 0.0103 \\
\hline 11 & Rib. dos Dourados & 1.3627 & .5101 & -49.6931 & -21.3648 & -49.6996 & 0.0021 & 0.0065 \\
\hline 12 & Rib. da Fartura & 21.3094 & -6.5595 & -49.7426 & -21.3026 & -49.7496 & -0.0068 & 0.0070 \\
\hline 13 & Rib. das Pintos & -21.2710 & -6.6733 & -49.8564 & -21.2662 & -49.8540 & -0.0048 & -0.0024 \\
\hline 14 & Rib. $d a$ Corr. & -21.2540 & -6.7111 & -49.8942 & -21.2428 & -49.9057 & -0.0112 & 0.0115 \\
\hline 15 & Rib. do Farello & -21.2472 & -6.7333 & -49.9164 & -21.2388 & -49.9178 & -0.0084 & 0.0014 \\
\hline 16 & Salto da Avanhandava & -21.2359 & -6.7673 & -49.9504 & -21.2140 & -49.9411 & -0.0219 & -0.0093 \\
\hline 17 & Porto 14 de Julho & -21.2201 & -6.8358 & -50.0189 & -21.2182 & -50.0178 & -0.0019 & -0.0011 \\
\hline 18 & Corr. Escaramusa & -21.2102 & -6.8734 & -50.0565 & -21.2094 & $\mid-50.0549$ & -0.0008 & -0.0016 \\
\hline 19 & Rib. do Lageado & -21.1886 & -6.9548 & -50.1378 & -21.1819 & -50.1298 & -0.0067 & -0.0080 \\
\hline 20 & Cach do Macuco & -21.1433 & -6.9655 & -50.1485 & -21.1450 & \begin{tabular}{|l|l|}
-50.1466 \\
\end{tabular} & 0.0017 & -0.0020 \\
\hline 21 & Corr. do Barreiro & -21.1205 & -7.0270 & -50.2101 & -21.1240 & -50.2077 & 0.0035 & -0.0024 \\
\hline 22 & C. Baguassí & -21.1152 & -7.0701 & -50.2532 & -21.1206 & -50.2503 & 0.0054 & -0.0029 \\
\hline 23 & Corr. do Matto Secco & -21.0963 & -7.0913 & -50.2744 & -21.1055 & -50.2729 & 0.0092 & -0.0015 \\
\hline 24 & Rib. Matto Grosso & -21.0487 & -7.1751 & -50.3582 & -21.0578 & \begin{tabular}{|l|l|}
-50.3449 \\
\end{tabular} & 0.0091 & -0.0133 \\
\hline 25 & Rib. Macahubas & -21.0334 & -7.2493 & -50.4324 & -21.0290 & -50.4395 & -0.0044 & 0.0071 \\
\hline 26 & Rib. Aracungud́ & -21.0008 & -7.3831 & -50.5661 & -20.9980 & -50.5589 & -0.0028 & -0.0072 \\
\hline 27 & Rib. Lambary & $\mid-20.9311$ & -7.4815 & -50.6646 & -20.9577 & -50.6309 & 0.0266 & -0.0337 \\
\hline 28 & Rib. d'Agua Parada & -20.8851 & -7.6207 & -50.8038 & -20.8783 & \begin{tabular}{|l|l|}
-50.7939 \\
\end{tabular} & -0.0068 & -0.0099 \\
\hline 29 & Rib. d" Água Fria & -20.8469 & -7.6783 & -50.8614 & -20.8319 & -50.8683 & -0.0150 & 0.0069 \\
\hline 30 & C. do Cotovello & -20.7588 & -7.8420 & -51.0251 & -20.7439 & -51.0381 & -0.0149 & 0.0130 \\
\hline 31 & Rib. Travessa Gr. & -20.6687 & -8.0189 & -51.2020 & -20.6574 & -51.2046 & -0.0113 & 0.0026 \\
\hline 32 & Corr. da I Secca & -20.6711 & -8.0848 & -51.2679 & -20.6522 & -51.2507 & -0.0189 & -0.0172 \\
\hline 33 & Rib. 3 Irmdos & -20.6848 & -8.1675 & -51.3506 & -20.6835 & -51.3531 & -0.0013 & 0.0025 \\
\hline 34 & Corr. Itapura Mirim & -20.6679 & -8.2871 & -51.4701 & -20.6707 & $\mid-51.4781$ & 0.0028 & 0.0080 \\
\hline 35 & Salto de Itapura & -20.6554 & -8.3394 & -51.5225 & -20.6538 & $\mid-51.5037$ & -0.0016 & -0.0188 \\
\hline \multirow[t]{3}{*}{36} & \multirow[t]{3}{*}{2 do Tiets } & \multirow[t]{3}{*}{-20.6610} & \multirow{3}{*}{-8.4263} & \multirow[t]{3}{*}{-51.6093} & \multirow[t]{3}{*}{-20.6304} & -51.5768 & -0.0306 & -0.0325 \\
\hline & & & & & & Mean $=$ & -0.0027 & -0.0083 \\
\hline & & & & & & Deviation $=$ & 0.0156 & 0.0179 \\
\hline
\end{tabular}


As a general assessment, except greater care in demarcating the control points, as pointed out, the method reaches its limit of accuracy, given the technology of the time.

e) Analysis of the river profile. Just below the general plan was draft the Tietê River profile. In it are represented: rapids, the backwaters (Rio Morto, Manso do Bacuri, etc.) and cascades. The horizontal scale is the same as the overall plan (1: 500,000), although apparently it has a greater extention than it. This is because the river meanders, that is, it has a greater development than the straight line joining its two ends. The vertical scale is 1: 2,500, for greater sensitivity for this dimension. In each position of the profile, the altitude of the point is recorded, from the Bar of Jacaré Grande to the Tietê Bar, at the base elevation of $250 \mathrm{~m}$ above the sea level.

\subsection{Partial plants in scale 1: 50,000}

There are 8 maps, scale 1: 50,000, on sheets numbered from I to VIII in the same geographic coordinate system as a determination similar to that for the general map. The ratio of the mesh openings in latitude and longitude could only be inferred (calculated) from the map of sheet IV, since it is the one that has sufficient lines of meridians and parallels for this. We recorded this map and extracted coordinates of rivers, waterfalls, cascades, streams, brooks and creeks to be compared with the map of the general layout of the Tietê River, which is done in Table 8. What is ultimately tested is the process compilation, since the general plan was drawn from the eight partials.

Table 8: Coordinates and respective differences between the General plan and Sheet IV

\begin{tabular}{|c|c|c|c|c|c|c|}
\hline \multirow{2}{*}{ Place } & \multicolumn{2}{|c|}{ General Plan } & \multicolumn{2}{|c|}{ Sheet IV } & \multicolumn{2}{|c|}{ Differences } \\
\hline & $\varphi$ & $\lambda$ & $\varphi$ & $\lambda$ & $\Delta \varphi$ & $\Delta \lambda$ \\
\hline Salto da Avanhandava & -21.2370 & -6.7638 & -21.2301 & -6.7593 & -0.0069 & -0.0045 \\
\hline Porto 14 de Julho & -21.2194 & -6.8347 & -21.2182 & -6.8328 & -0.0012 & -0.0019 \\
\hline Corr. escaramuça & -21.2123 & -6.8718 & -21.2094 & -6.8773 & -0.0029 & 0.0055 \\
\hline Rib. S. Jeronymo & -21.2109 & -6.8848 & -21.2100 & -6.8801 & -0.0009 & -0.0047 \\
\hline Rib. do Lageado & -21.1888 & -6.9541 & -21.1921 & -6.9517 & 0.0033 & -0.0024 \\
\hline Cach. do Macuco & -21.1439 & -6.9635 & -21.1450 & -6.9710 & 0.0011 & 0.0075 \\
\hline Rib. S. Barbara & -21.1414 & -6.9650 & -21.1438 & -6.9738 & 0.0024 & 0.0088 \\
\hline Corr. do Barreiro & -21.1208 & -7.0246 & -21.1240 & -7.0337 & 0.0032 & 0.0091 \\
\hline C. Baguassú & -21.1172 & -7.0672 & -21.1206 & -7.0767 & 0.0034 & 0.0095 \\
\hline Corr. do Matto Secco & -21.0970 & -7.0898 & -21.1055 & -7.0988 & 0.0085 & 0.0090 \\
\hline & & & & Mean $=$ & 0.0010 & 0.0036 \\
\hline & & & & Deviation $=$ & 0.0042 & 0.0062 \\
\hline
\end{tabular}

This table allows observing that the compilation was well made, and the systematic error (average) and precision (standard deviation) equal to or smaller than half of the existing systematic error in the General plan, as can be seen in Table 7, which is a consistent result, also because of the 
compilation process requires the removal and simplification of elements (curves and widths, for example).

\section{Quality of the cartographic representation}

By means of a visual analysis of these products, we find its good cartographic quality representation, as shown in Figure 4, in which we see the VIII sheet, scale 1: 50,000. It first highlights the good use of colors: black, blue for hidrography, sepia (light brown) to the contour curves; the quality of letters and numbers, using templates for the letters; the use of dashes and other cartographic conventions, despite not explicitly included in a caption and, in general, the perfection of the lines, the details of cross sections, islands and waterfalls and cascades . This figure is very rich: in addition to the cross-sections, others drawings appear in the scale 1: 5,000: the Avanhandava and Macuco waterfalls, paths, cross, mill, houses, direction of the current, widths and other details.

The quality of design is undoubtedly a legacy of Teodoro Sampaio, and influenced by the works of the Coast and Geodetic Survey, recognized in other CGG reports. All this, in addition to the technical aspects already analyzed: determination of geographical coordinates using a map projection and others.

\section{Conclusion}

By means of analyses and evaluations, it was concluded that the cartographic survey and plans drawn up by CGG was very well made, reaching a satisfactory precision for the technology of the time. It is hence a work of high scientific, documentary, cartographic and historical value. Worthy therefore of analysis, study and dissemination, things for which we hope to have contributed. 


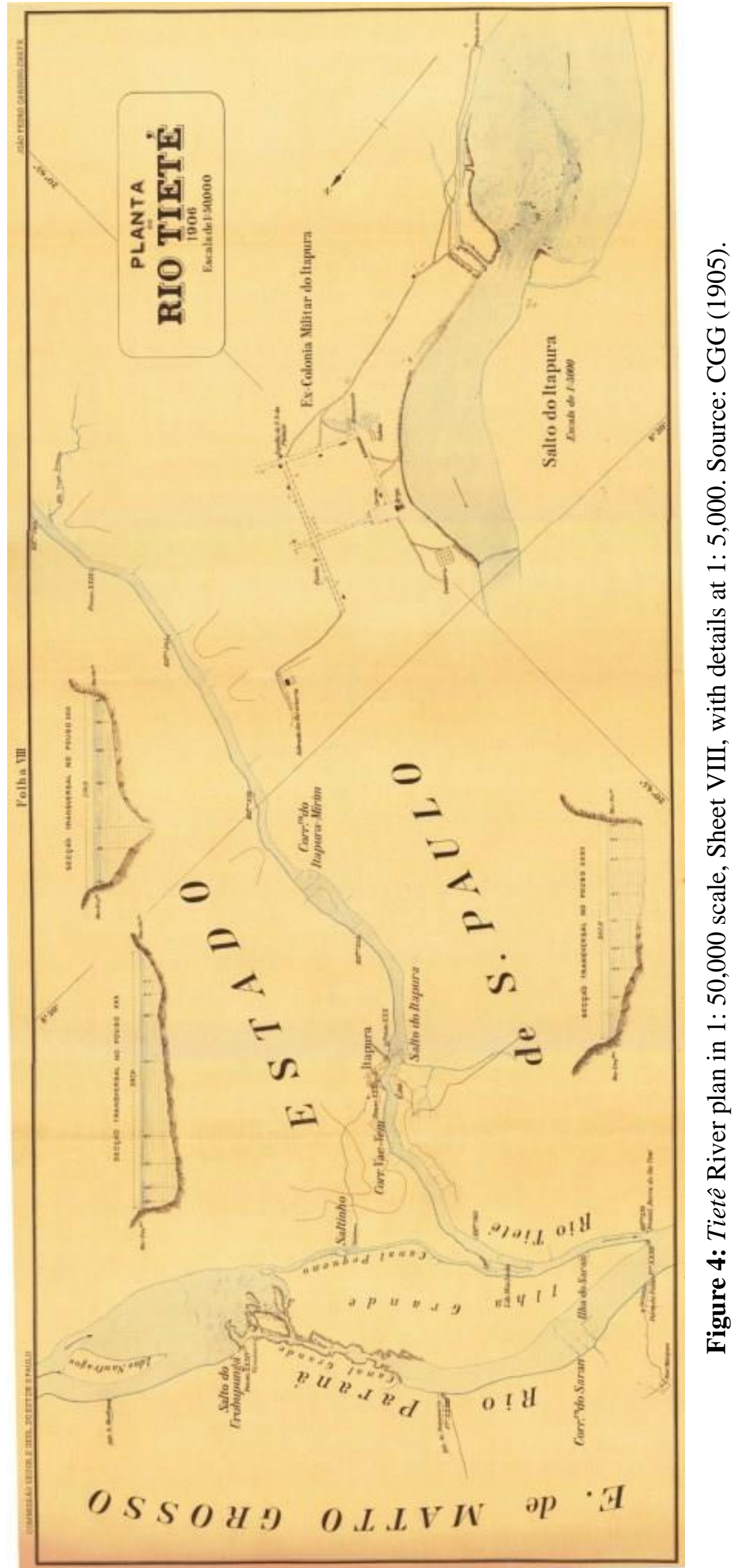

Bol. Ciênc. Geod., sec. Artigos, Curitiba, v. 23, no2, p.309 - 326, abr - jun, 2017. 


\section{REFERENCES}

CGG - Commissão Geographica e Geológica do Estado de S. Paulo. Exploração do Rio Tietê (Barra do Rio Jacaré-Guassú ao Rio Paraná) - 1905. São Paulo, 3ª Edição, 1930.

Cintra, J. P. and Silva, M. J. . Teodoro Sampaio and the Beginning of Systematic Cartography in Brazil. In: Congreso Internacional de Geodesia y Cartografia, 2002, Caracas. Memorias del Congreso Internacional de Geodesia y Cartografia, 2002. v. 1. p. 1-6

Cintra, J.P. \& Freitas, J.C. (2011) Sailing Down the Amazon River: La Condamine's Map, Survey Review, 43:323, 550-566 To link to this article: http://dx.doi.org/10.1179/003962611X13117748892119

Figuerôa, S. F. de M. Modernos bandeirantes: a Comissão Geográfica e Geológica de São Paulo e a exploração científica do território paulista (1886-1931). Dissertação de Mestrado, FFLCHUSP, 1987.

Figuerôa, S. F. de M. Um século de pesquisas em Geociências. 1. ed. São Paulo: Instituto Geológico de SP, 1985. v. 1. 96p .

Figuerôa, S. F. de M.. 'Batedores da ciência' em território paulista: expedições de exploração e a ocupação do 'sertão' de São Paulo na transição para o século XX. Hist. cienc. saude-Manguinhos, Rio de Janeiro, v. 15, n. 3,p. 763-777, Sept. 2008. Available at http://dx.doi.org/10.1590/S0104$\underline{59702008000300010}$

Gaspar, J. A. (2005) Cartas e projeções cartográficas, Lidel Edições Técnicas, 2005

Lucio, S. T. M. P. João Pedro Cardoso e a ação da Comissão Geográfica e Geológica na apropriação e produção do território paulista, 1905-1931. 2014. Tese (Doutorado em História e Fundamentos da Arquitetura e do Urbanismo) - Faculdade de Arquitetura e Urbanismo, Universidade de São Paulo, São Paulo, 2014. Available at: http://www.teses.usp.br/teses/disponiveis/16/16133/tde-19122014-134113

Moi, C. Explorações do olhar: ciência e arte nas fotografias da Comissão Geográfica e Geológica de São Paulo, 2005. 169 p. Dissertação de Mestrado em Multimeios, Instituto de Artes da UNICAMP, Campinas, 2005.

Taliberti, L. Tres quartos de século de serviços geográficos e geológicos prestados a São Paulo, O IGC, Revista do Instituto Geográfico e Geológico, vol. XV, 1961-1962, Secretaria da Agricultura, p. 19-36. São Paulo.

Recebido em 22 de junho de 2016.

Aceito em 27 de outubro de 2016. 